JURNAL PANGKAJA PROGRAM PASCASARJANA UNIVERSITAS HINDU NEGERI I GUSTI BAGUS SUGRIWA DENPASAR
Vol.24, No. 2, September 2021

ISSN : 1412-7474 (Cetak)

ISSN : 2623-2510 (Online)

http://ejournal.ihdn.ac.id

\title{
PERBEDAAN AGAMA DENGAN AKULTURASI TRADISI SUBAK DALAM MEMPENGARUHI PSIKOLOGIS, KARAKTER, DAN PERILAKU MASYARAKAT
}

\author{
Kadek Ari Setia Utama Putra ${ }^{1}$, Kadek Ari Anggarini' ${ }^{2}$, \\ Putu Pande Pinandia Eka Putri ${ }^{3}$, Ni Komang Sutriyanti ${ }^{4}$ \\ SMA Negeri Bali Mandara ${ }^{1,2,3}$, UHN I Gusti Bagus Sugriwa Denpasar ${ }^{4}$ \\ Email: arisetiautama1401@ gmail.com ${ }^{1}$, arianggarini4@ gmail.com ${ }^{2}$, \\ pandepinandia@gmail.com ${ }^{3}$, nikomangsutriyanti@gmail.com ${ }^{4}$
}

\begin{abstract}
Bali is inseparable from its culture and local wisdom which is combined with the culture of other religious communities, one of which is the acculturation of Subak culture carried out by Hindus and Muslims. Various things happened in Indonesia regarding the incidence of diversity intolerance, so that the community formed a community organization in Bali that regulates water for rice fields from a water source in an area whose members consist of a combination of Hindus and Muslims living in rural areas. This organization was formed by the community to maintain community harmony and was used as a forum for forming cultural acculturation. The maintenance of the Subak cultural acculturation carried out in Yeh Embang Village, Mendoyo, Jembrana is able to change the psychology of the community in influencing the character and behavior of the community. The objectives to be achieved in this study are to describe the existence of Subak culture in today's modern era, to analyze the process of cultural acculturation between Hindus and Muslims in Subak Yeh Santang, and to analyze the impact of acculturation of Subak culture between Hindus and Muslims on the psychological and character of society. The research instruments include interviews, questionnaires, documentation, objects of observation and books and journals. The data obtained were analyzed using qualitative descriptive methods. The results of this study are as follows; Acculturation of Subak culture can strengthen harmony between residents or the community and there is a positive impact of acculturation of Subak culture on the psychology, mindset, and behavior of the community which affects the character of the community in a better direction with a percentage of the influence of Subak cultural acculturation on the psychology of society by $87 \%$ and the role of the community $78.11 \%$ indicates that the community plays a very important role in the implementation of this cultural acculturation.
\end{abstract}

Keywords: Cultural acculturation, Subak, psychological.

\begin{abstract}
ABSTRAK
Bali tidak terlepas dari budaya dan kearifan lokalnya yang dipadukan dengan budaya dari umat agama lain salah satunya adalah akulturasi budaya Subak yang dilaksanakan oleh Umat Hindu dan Umat Islam. Berbagai hal yang terjadi di Indonesia mengenai peristiwa intoleransi keberagaman, sehingga masyarakat membentuk sebuah organisasi masyarakat di Bali yang mengatur air untuk persawahan dari suatu sumber air di dalam suatu daerah yang anggotanya terdiri dari gabungan Umat Hindu dan Umat Islam yang tinggal di daerah pedesaan. Organisasi ini dibentuk masyarakat untuk menjaga keharmonisan masyarakat dan
\end{abstract}


digunakan sebagai wadah dalam membentuk akulturasi budaya. terjaganya akulturasi budaya Subak yang dilaksanakan di Desa Yeh Embang, Mendoyo, Jembrana mampu mengubah psikologis masyarakat dalam memengaruhi karakter dan perilaku masyarakat. Adapun tujuan yang ingin dicapai pada penelitian ini adalah mendiskripsikan eksistensi budaya Subak pada era modern saat ini, menganalisis proses adanya akulturasi budaya antara Umat Hindu dan Islam di Subak Yeh Santang dan, menganalisis dampak akulturasi budaya Subak antara Umat Hindu dan Islam terhadap psikologis dan karakter masyarakat. Instrument penelitian ini meliputi wawancara, kuesioner, dokumentasi, objek pengamatan serta buku dan jurnal. Data yang diperoleh dianalis dengan metode deskriptif kualitatif. Adapun hasil penelitian ini sebagai berikut; akulturasi budaya Subak dapat mempererat keharmonisan antar warga atau masyarakat dan adanya dampak positif dari akulturasi budaya Subak terhadap psikologis, pola pikir, dan perilaku masyarakat yang memengaruhi karakter masyarakat kearah yang lebih baik dengan persentase pengaruh akulturasi budaya Subak terhadap psikologis masyarakat sebesar $87 \%$ dan peran masyarakat sebesar $78,11 \%$ menunjukkan bahwa masyarakat berperan sangat penting dalam pelaksanaan akulturasi budaya ini.

Kata kunci: Akulturasi budaya, Subak, psikologis.

\section{PENDAHULUAN}

Indonesia merupakan negara yang memiliki banyak keragaman dari budaya, suku bangsa, agama, hingga aliran-aliran kepercayaan. Semua keragaman tersebut tumbuh di dalam kehidupan masyarakat Indonesia yang akhirnya membentuk masyarakat Indonesia sebagai masyarakat yang plural. Masyarakat Indonesia yang majemuk terdiri dari berbagai budaya, karena adanya kegiatan dan pranata khusus. Indonesia merupakan negara yang memiliki kearifan lokal budaya yang sangat kuat dengan penggabungan suatu budaya tanpa mengubah Eksistensi dari budaya tersebut. Salah satunya Pulau Bali sebagai provinsi yang memiliki tradisi, budaya, dan komitmen religius tersendiri yang sangat kuat dengan kesakralannya yang masih dipertahankan sampai sekarang. Namun, masyarakat Bali memiliki moral atau perilaku yang terbuka sehingga mudah dalam melakukan pergaulan. Hal ini dibuktikan dengan kearifan lokal yang digabungkan oleh masyarakat Bali dengan orang Muslim yang berada di desa-desa di Bali seperti contohnya di Jembrana yang terdapat kampung muslim bernama kampung Loloan, Buleleng dengan nama Kampung Pegayaman, Kelungkung dengan nama Kampung Gelgel, Karangasem dengan nama Kampung Kecicang Islam (Qupas, 2018). Penduduk menjadikan budaya sebagai bahan dalam menjaga suatu kerukunan antar Umat Hindu dengan umat lainnya.

Di Bali terdapat 3.890.757 jiwa penduduk yang mayoritas orangnya memeluk Agama Hindu dan minoritas orangnya memeluk agama lainnya. Banyak orang Muslim yang bermigrasi ke Bali dan menetap di Bali sehingga pada desa tersebut sering diberikan nama "Kampung Muslim". Namun, di Bali tetap menjalin toleransi antar Umat Hindu dan umat lainnya. Toleransi tersebut timbul menjadi akulturasi dalam Agama Hindu dan Agama Islam dengan memadukan sebuah perbedaan menjadi persamaan agar terjalinnya hubungan yang

harmonis antara Umat Hindu dan umat lainnya. Hal tersebut membuktian bahwa di Bali terjadi toleransi antar pemeluk agama sehingga menimbulkan adanya akulturasi budaya. Akulturasi merupakan pengambilan atau penerimaan satu atau beberapa unsur kebudayaan yang berasal dari pertemuan dua atau beberapa unsur kebudayaan yang saling berhubungan atau saling bertemu (Suyono, 2006). Dengan adanya akulturasi ini, timbuhlah beragam hubungan yang erat antara Agama Hindu dan Agama Islam yang tinggal pada daerah tersebut dan itu sudah ada dari dulu sampai sekarang yang sudah terbukti terjadi di Kabupaten Jembrana. Tradisi ini dilaksanakan tepatnya di Kecamatan Mendoyo, kabupaten 
Jembrana. Tradisi tersebut dapat membentuk rasa solidaritas dari masyarakat yang kuat dengan menggunakan sistem Subak yang memang sudah dilaksanakan oleh orang Bali dan sekarang sistem tersebut juga diterapkan oleh orang Muslim yang tinggal pada daerah tersebut. Ini membuktikan bahwa perbedaan agama tidak menjadi suatu penghalang dalam membentuk solidaritas beragama. Hal itu sudah tertera di bawah kaki Burung Garuda pada Pancasila yang bertuliskan "Bhinekka Tunggal Ika" yang artinya "Berbeda-beda tetapi tetap satu tujuan", perbedaan tidak menjadi hal yang membuat hubungan atau kerukunan di negara menjadi runtuh atau pecah.

Keberadaan Subak di Bali sudah diresmikan oleh pemerintah dengan mengeluarkan Peraturan Daerah No.02 tahun 1972 tentang irigasi Daerah Provinsi Bali. Peraturan ini mengatur tentang mekanisme kelembagaan pengelola irigasi di Bali. Sistem Subak merupakan suatu warisan budaya Bali yang berupa suatu sistem irigasi yang mengatur pembagian pengelolaan airnya yang berdasarkan pada pola pikir harmoni dan kebersamaan yang berlandaskan pada aturan-aturan formal dan nilai-nilai agama. Pengelolaan sistem irigasi konvensional cenderung hanya berdasarkan pada konsep-konsep efisiensi berdasarkan aturan-aturan formal, dengan sistem irigasi tersebut akan meningkatkan pola pikir masyarakat untuk meningkatkan peluang ekonomi masyarakat. Baiknya hubungan masyarakat Hindu dengan Agama Islam dan banyak juga tradisi sehingga perpaduan budaya tersebut juga digunakan oleh masyarakat Muslim di Jembrana dalam mengairi persawahan mereka. Ini menunjukan di desa tersebut sudah adanya perpaduan budaya yang dilaksanakan oleh orang Muslim yang tinggal di sana.

Dengan adanya penggabungan suatu budaya maka terdapat pengaruh yang akan membuat pemikiran atau psikologis manusia menjadi lebih baik karena pada sistem Subak menggunakan prinsip gotong royong dan tolong-menolong. Dalam tradisi ini sangat membantu masyarakat dalam menjaga hubungan atau rasa toleransi dari masyarakat menjadi lebih baik dan dapat mengurangi adanya pertentangan atupun penyimpangan sosial pada daerah tersebut. Kerukunan Umat beragama pada daerah sangat diperlukan, banyak desa atau kota yang terdapat warga dengan agama berbeda saling bertentangan, konflik karena masalah agama, tradisi dan keyakinan yang berbeda seperti konflik antar agama terjadi di Aceh kota Singkil pada tahun 2015 yang di awali dengan serangkaian demonstrasi dilakukan oleh sebagian Umat Islam yang menuntut pemerintah daerah dalam membongkar sejumlah geraja Kristen dan terjadinya perusakan pura di Lumajang pada tahun 2018 yang melibatkan Umat Hindu dengan Umat Islam. Cara mengatasi masalah tersebut adalah dengan melakukan hubungan melalui akulturasi budaya.

Oleh karena itu, peneliti ingin mengetahui penyebab terjadinya akulturasi budaya dan pengaruh yang akan ditimbulkan oleh akulturasi budaya yang dilaksanakan oleh dua agama berbeda terhadap kondisi psikologis manusia dalam mempengaruhi perilaku dan karakter ketika orang yang agama lain melaksanakan budaya tersebut dan dampak yang akan terjadi pada eksistensi dan proses jalannya saat agama lain melaksanakan budaya orang Bali. Merujuk dari pembahasan tersebut, maka dipandang perlu untuk melakukan penelitian terkait "Perbedaan Agama dengan Akulturasi Tradisi Subak dalam Mempengaruhi Psikologis, Karakter, Dan Perilaku Masyarakat".

Berangkat dari latar belakang, adapun rumusan masalah dari penelitian ini adalah; eksistensi tradisi Subak pada zaman modern saat ini? Bagaimana proses terjadinya akulturasi budaya Subak antara Umat Hindu dan Islam di Mondoyo? Apakah akulturasi budaya Subak antara Umat Hindu dan Islam berpengaruh terhadap perubahan psikologis dan karakter masyarakat?

Adapun tujuan yang ingin dicapai pada penelitian ini adalah mengetahui bagaimana eksistensi Subak pada zaman modern ini, menganalisis tentang proses terjadinya akulturasi budaya Subak antara Umat Hindu dan Islam di Mendoyo, mendeskripsikan tentang dampak 
terjadinya akulturasi budaya Subak oleh Umat Hindu dan Islam terhadap psikologis dan karakter masyarakat.

Teknik pengumpulan data dari penelitian ini menggunakan; wawancara, observasi, angket kuesioner, dan telaah pustaka. Dalam penelitian ini peneliti menggunakan skala pengukuran ordinal. Skala ordinal merupakan skala yang memberi informasi tentang jumlah karakteristik berbeda yang dimiliki oleh objek-objek tertentu. Dalam hal ini metode pengukuran digunakan untuk memberikan penilaian kuesioner. Skor penilaian kuesioner menggunakan skala likert, yaitu skala untuk mengungkapkan persepsi responden dengan memilih salah satu dari lima alternatif pilihan yang tersedia.

Teknik analisis data yang digunakan dalam penelitian ini adalah mengumpulkan data yang diperoleh dari jurnal, buku, penelusuran data dan informasi melalui internet, serta observasi dan wawancara dikumpulkan kemudian dianalisis menggunakan metode deskriptif kualitatif. Deskriptif kualitatif merupakan data yang digambarkan dengan kata-kata atau kalimat yang dipisah pisah menurut kategori, untuk memperoleh simpulan. Analisis ini dilakukan untuk memperoleh perbedaan antara data-data yang telah diperoleh. Data yang diperoleh digunakan untuk menarik kesipulan dari penelitian ini.

\section{PEMBAHASAN}

\section{Eksistensi Tradisi Subak di Masyarakat pada Zaman Modern Saat Ini}

Kata Subak merupakan sebuah kata yang berasal dari bahasa Bali, kata tersebut pertama kali dilihat di dalam prasasti Pandak Bandung yang memiliki angka tahun $1072 \mathrm{M}$. Kata Subak tersebut mengacu kepada sebuah lembaga sosial dan keagamaan yang unik, memiliki pengaturan tersendiri, asosiasi-asosiasi yang demokratis dari petani dalam menetapkan penggunaan air irigasi untuk pertumbuhan padi. Di Bali hampir setiap desa memiliki Subak. Salah satunya adalah desa Mendoyo dengan Subak yang bernama Subak Yeh Santang. Subak Yeh Santang memiliki tujuan dan Budaya yang sama dengan Subak yang lain. Tetapi ada satu hal yang membuat Subak Yeh Santang berbeda dengan Subak lain yakni anggota dari Subak Yeh Santang terdiri dari Umat Hindu dan Islam.

Subak merupakan suatu organisasi dan sebuah tradisi turun temurun yang mengatur tentang sistem irigasi persawahan di Bali. Di Bali sawah sangatlah penting karena sawah para penduduk Bali mendapatkan uang untuk memenuhi kebutuhan hidup, itu sebabnya masyarakat Bali sangat mempertahankan dan melestarikan budaya Subak sampai saat ini. Bukan itu saja, sistem Subak erat kaitannya dengan kebudayaan masyarakat Bali yang dikenal penuh dengan kebersamaan, gotong royong, keharmonisan, dan hidup bersama saling membantu satu sama lain. Subak memakai konsep Tri Hita Karana yaitu 3 penyebab kesejahteraan yang terdiri dari parhyangan, pawongan dan palemahan. Parhyangan yaitu setiap Subak mempunyai pura tersendiri yang disebut Pura Subak atau Pura Ulun Carik, Pura Bedugul atau Pura Ulun Empelan sebagai unsur Ketuhanan di dalam Subak itu sendiri. Yang kedua pawongan yaitu Subak mempunyai anggota yang disebut Krama Subak atau di beberapa tempat disebut Krama Carik sebagai unsur kemasyarakatan, selain itu juga dari anggota Subak memiliki kebersamaan dan kepedulian yang tinggi terhadap sesamanya dan itu semua untuk kepentingan bersama untuk Krama Subak. Yang terakhir adalah palemahan, Subak mempunyai wilayah atau areal pertanian dengan batas alam tertentu seperti sungai, jalan, pematang besar, desa, dan lain-lain (Nopitasari, 2010). Dengan menggunakan konsep Tri Hita Karana diharapkan Subak mampu memperkuat hubungan manusia dengan manusia, alam dan Tuhan sehingga akan terjadi sebuah keseimbangan kehidupan di Bali.

Budaya Bali yang selalu diunggulkan adalah bahwa masyarakat Bali begitu harmonis dalam menjalankan kehidupan, hal itu dapat terwujud dalam sistem Subak ini. Dalam Subak keadilan juga di tetapkan pada saat pembagian air untuk irigasi persawahan. Tujuan tradisi Subak adalah untuk dapat meningkatkan perekonomian masyarakat tanpa mengubah suatu 
budaya dan mencapainya dengan cara bergotong royong tanpa adanya konflik dan pertentangan. Namun, seiring perkembangan zaman, pembangunan untuk pariwisata semakin banyak yang secara langsung dan tidak langsung telah mengganggu sistem Subak di Bali. Karena sulitnya mencari sumber air untuk irigasi persawahan. Berkembangnya sektor pariwisata tidak menutup kemungkinan akan menurunkan eksistensi Subak di Bali bahkan seluruh dunia, karena dengan bertumbuhnya sektor pariwisata akan membuat pudarnya kebudayaan dari Subak dan seiring berkembangnya zaman budaya Subak akan hilang.

Tetapi kerja keras Pemerintah dan para petani di Bali untuk mempertahankan dan melestarikan Subak tidak sia-sia, karena Subak di Bali ditetapkan sebagai situs Warisan Dunia pada Sidang Komite Warisan Dunia ke-36 Organisasi Pendidikan, Ilmu Pengetahuan, dan Kebudayaan Perserikatan Bangsa-Bangsa (UNESCO di Saint Petersburg, Rusia, Jum'at (29/6). Subak masuk daftar warisan dunia setelah pemaparan rekomendasi dari Internasional Council on Monuments and Sites (Icomoc) yang di bacakan oleh Susan Deyner (Kompas, 2012). Sampai sekarang eksistensi budaya Subak masih berkembang di masyarakat, bahkan sekarang Subak tidak hanya dilaksanakan oleh Umat Hindu tetapi Umat Islam yang menetap di Bali juga ikut bergabung sehingga masyarakat Islam juga akan mendapatkan hasil dari budaya Subak di Bali.

Anggota Subak atau juga bisa disebut dengan Krama Subak adalah para petani yang memiliki garapan sawah dan mendapatkan bagian air pada sawahnya. Di dalam anggota Subak juga terdapat beberapa kelompok yang disebut dengan Sekaa, Krama Subak digolongkan menjadi 3, yaitu: Krama aktif adalah anggota yang aktif seperti Krama Pekaseh, Sekaa Yeh atau Sekaa Subak. Krama pasif yaitu anggotayang mengganti dengan uang karena beberapa penyebab yang bisa disebut dengan Pengampel atau Pengohot. Krama Luput yaitu anggota (Krama) yang tidak aktif di dalam segala macam kegiatan Subak karena tugasnya seperti kepala desa atau Bendesa Adat. Dalam Subak juga memiliki Pengurus (Prajuru) Subak yang terdiri dari Pekaseh yang memiliki peran memimpin setiap rapat-rapat subak, baik yang berkaitan dengan internal organisasi Subak maupun yang berkaitan dengan lembaga di luar Subak, seperti misalnya Dinas Pertanian, Sedahan, atau dinas terkait lainnya sesuai kepentingan Subak. Pekaseh mempunyai garis perintah ke Keliantempek.

Sekretaris berperan membantu Pekaseh khususnya mengerjakan hal-hal yang bersifat administratif atau dapat memimpin pertemuan jika Pekaseh berhalangan. Bendahara berperan dalam melakukan pembukuan dan mengelola keuangan subak. Kelian Munduk atau Kelian Tampek berperan dalam memimpin kegiatan-kegiatan dalam lingkup Tempek disamping dapat sebagai perwakilan Tempek jika diadakan rapat Subak. Kasinoman berperan membantu Keliantempek untuk menyampaikan informasi yang terkait dengan Subak atas permintaan Pekaseh. Ketua bidang atau seksi-seksi berperan dalam membantu Pekaseh untuk memimpin dan mengembangkan bidang-bidang tertentu yang ditetapkan ada dalam kepengurusan Subak. Pemangku bertugas khusus dalam urusan ritual/keagamaan, Pemangku memiliki peran yang sangat penting karena sebelum Krama Subak mulai bekerja akan dilakukan sebuah ritual keagamaan untuk memuja Dewi Sri selaku dewi kesuburan dan kemakmuran yang dipercaya oleh Umat Hindu di Bali.

Kelompok Sekaa di dalam Subak dibagi menjadi; Sekaa Numbeg, yaitu sebuah kelompok yang mengatur hal pengolahan tanah. Sekaa Jelinjingan, kelompok yang bertugas untuk mengatur pengolahan air. Sekaa Sambang, yaitu kelompok yg memiliki tugas dalam hal pengawasan air dari pencurian, penangkap atau penghalau binatang perusak tanaman seperti burung maupun tikus. Sekaa Memulih/Nandur, yaitu kelompok yang bertugas dalam hal penanaman bibit padi. Sekaa Mejukut, yaitu kelompok yang bertugas menyiangi padi. Sekaa Manyi, adalah kelompok yang bertugas memotong atau mengetam padi. Sekaa 
Bleseng, yaitu kelompok yang memiliki tugas mengangkut ikatan padi yang telah diketam dari sawah ke lumbung.

Ada beberapa ritual keagamaan yang dilakukan sebelum melaksanakan Subak yaitu upacara yang dilakukan secara perorangan dan upacara yang dilakukan secara berkelompok. Upacara yang dilakukan secara perorangan diantaranya Ngendagin/Mamungkah/Nuasen Tesun. Upacara ini dilakukan pada saat memulai kegiatan di sawah untuk bertanam. Tujuannya sebagai permakluman pada Tuhan atau dewa-dewi yang berada di sawah. Kemudian Upacara Ngawitwit yang dilaksanakan pada waktu petani menabur benih di pembibitan. Selanjutnya ada upacara Nuasen Nandur yang dilaksanakan pada saat akan menanam padi. Tujuannya memohon kepada Tuhan agar proses penanaman padi berjalan lancar. Lalu, upacara Ngulapin dilakukan setelah selesai menanam padi atau ada padi yang rusak. Upacara Ngeroras dilakukan saat padi berumur 12 hari. Mubuhin saat padi berusia 15 hari. Neduh saat padi berusia satu bulan. Nyungsung/Ngiseh saat padi berusia 42 hari. Lalu Mabiukukung saat padi mulai bunting atau bisaanya berusia 70 hari. Tujuannya sama, adalah memohon agar padi tumbuh dengan baik dan terhindar dari serangan hama. Upacara selanjutnya adalah Nyangket atau Mabanten Manyi yang dilakukan saat panen. Upacara Mantenin yang dilakukan pada saat padi disimpan di lumbung sebelum diolah menjadi beras. Sedangkan, untuk upakara secara berkelompok ada Mapag Toya yang dilakukan oleh Subak pada saat mengalirkan air untuk pertama kali. Bisa dilakukan pada lokasi sumber air. Kemudian, Nedun yang bisaa dilakukan Subak di Pura Bedugul atau Ulunsuwi dengan tujuan meredam serangan hama tanaman. Ada juga Ngusaba Nini, dimana upacara ini dilakukan Subak menjelang panen dengan mengumpulkan Nini sebagai perwujudan Dewi Sri sebagai dewi kesuburan dengan maksud mengucapkan terima kasih dan syukur atas segala karunia dan memohon keselamatan.

Subak di laksanakan oleh Umat Hindu di Bali dengan tata cara pengairan sawah tradisional. Dalam melaksanakan Subak Umat Hindu juga melaksanakan persembahyangan dengan tata cara Agama Hindu yang ditujukan kepada Dewi Sri yang di percaya sebagai dewi kemakmuran dan kesuburan. Tidak semua Subak dilaksanakanan oleh Umat Hindu tetapi Umat yang beragama lain ikut juga dalam melaksanakan Subak tersebut, seperti Subak Yeh Santang di kecamatan Mendoyo-Jembrana, Bali. Subak Yeh Santang dilaksanakan oleh Umat Hindu dan Islam.

\section{Proses Tejadinya Akulturasi Budaya Subak antara Umat Hindu dan Islam di Subak Yeh Santang, Mendoyo}

Tradisi Subak adalah tradisi turun temurun Umat Hindu yang mengatur tentang irigasi persawahan di Bali. Hampir di setiap kabupaten dan setiap desa di Bali memiliki Subak untuk mengatur irigasi sawah mereka. Subak telah dilaksanakan oleh Umat Hindu sejak dulu sebelum Umat Islam memasuki pulau Bali. Alasan Umat Hindu melaksanakan Subak terutama para petani adalah untuk memperlancar irigasi persawahan yang ada di Bali. Namun, kedatangan Umat Islam di Bali khususnya di Mendoyo membuat Umat Hindu harus beradaptasi kembali. Umat Islam dan Umat Hindu bekerja sama mengurus Subak Yeh Santang yang menyebabkan terjadinya akulturasi budaya di antara kedua agama yang berbeda. Akulturasi budaya Subak ada karena Umat Islam mulai ikut dalam organisasi Subak Yeh Santang di Mendoyo, Jembrana. Umat Hindu menerima sangat baik kedatangan Umat Islam dan ikut bergabung di sawah mereka. Sedikit demi sedikit Umat Islam belajar tentang tata cara pengairan di sawah. Umat Hindu memberikan ilmu kepada Umat Islam yang diterima baik oleh Umat Islam sehingga Umat Islam dengan cepat mampu untuk mengolah irigasi persawahan di Subak Yeh Santang. Subak memerlukan banyak orang untuk mengelolanya karena itulah masyarakat Islam juga ikut bergabung ke dalam Subak Yeh Santang berbekal ilmu dan cara-cara yang diberikan oleh Umat Hindu. Karena seringnya bekerja di sawah bersama-sama menimbulkan perasaan semangat dan bahagia di setiap 
petani yang bekerja. Menurut I Nengah Suda yang sudah bertahun-tahun sebagai petani di Subak Yeh Santang, bekerja sama dengan Umat Islam sangat menyenangkan karena tidak ada lagi perbedaan yang dimiliki oleh keduanya, melainkan sebagai saudara dan saling tolong-menolong.

Dengan bekerja sama menimbulkan rasa kekeluargaan yang tinggi antara kedua agama tersebut. Mereka menjadi mampu untuk menghapus semua perbedaan yang ada diantara keduanya dan di gantikan dengan rasa memiliki yang tinggi dan menjadi saling ketergantungan. Hal itulah yang akan mampu menjaga eksistensi dari Subak yang ada di Bali sehingga budaya Subak tidak hilang dimakan waktu melainkan semakin berkembang dengan inovasi baru tetapi tanpa mengubah tujuan dan budaya Subak sebelumnya.

\section{Dampak Akulturasi Budaya Subak antara Umat Hindu dan Islam terhadap Psikologis dan Karakter Masyarakat}

Dampak dari akulturasi budaya tidak hanya untuk para petani Hindu maupun Islam di sawah, melainkan berdampak pada perilaku sehari-hari masyarakat. Hal itu di buktikan bahwa masyarakat Islam dan Hindu di Mendoyo menjalin toleransi yang sangat baik. Kebersamaan yang dijalani bersama di sawah membuat mereka saling menghormati tradisi masing-masing agama. Menurut I Nyoman Suardika selaku warga di Kecamatan Mendoyo menyatakan bahwa kerukunan Umat Hindu dan Umat Islam berjalan sangat baik bahkan ketika hari raya keagamaan. Masing-masing agama saling berkunjung atau bersilaturahmi ke rumah masing-masing penduduk. Hal itu dapat terjadi karena pola pikir masyarakat sudah berdalih kepada rasa memiliki satu sama lain. Selain di sawah, masyarakat juga bisa menghargai tradisi turun temurun dan menyebabkan eksistensi Subak berkembang menjadi lebih baik.

Sering bergotong royong dalam bekerja di sawah mengakibatkan adanya kebersamaan dan menghasilkan perubahan pola pikir masyarakat, sehingga penyimpanganpenyimpangan di masyarakat menjadi berkurang. Karena pola pikir masyarakat telah berdalih menjadi pola pikir yang mementingkan rasa persaudaraan dan kekeluargaan. Dengan berubahnya pola pikir masyarakat secara otomatis dapat mengubah perilaku masyarakat, sehingga terciptanya karakter masyarakat yang baru yaitu karakter yang terbentuk dalam pelaksanaan Subak. Karakter yang baru tentunya akan dapat memengaruhi kehidupan masyarakat kedepannya dan juga akan mempengaruhi perkembangan dan eksistensi Subak kedepannya. Akulturasi budaya Subak sangat berperan penting untuk mencapai hal tersebut karena ketika adanya sebuah akulturasi budaya maka budaya tersebut akan mampu berkembang dan bereksistensi di masyarakat, hal itu yang mendorong masyarakat untuk mengikuti budaya Subak dan menjalin persaudaraan dengan masyarakat lainnya.

\section{Hasil Penelitian Berdasarkan Kusioner}

Berdasarkan kuesioner yang telah disebarkan kepada 10 petani dan 10 pelajar di desa Mendoyo- Jembrana, didapat data sebagai berikut.

Tabel 1. Data Hasil Kuesioner Masyarakat Desa Mendoyo terhadap Budaya Subak dan Akulturasi Budaya Subak antara Umat Hindu dan Islam

\begin{tabular}{|c|l|c|c|c|}
\hline No. & \multicolumn{1}{|c|}{ Indikator } & Total Nilai & Nilai Maksimal & Persentase (\%) \\
\hline 1. & $\begin{array}{l}\text { Pendapat masyarakat tentang } \\
\text { organisasi atau tradisi Subak yang ada } \\
\text { di Bali }\end{array}$ & $\mathbf{7 6 0}$ & $\mathbf{9 0 0}$ & $\mathbf{8 4 , 4 4 \%}$ \\
\hline $\mathbf{2 .}$ & $\begin{array}{l}\text { Pandangan masyarakat tentang } \\
\text { pentingnya organisasi Subak yang ada } \\
\text { di Bali }\end{array}$ & $\mathbf{5 6 9}$ & $\mathbf{7 0 0}$ & $\mathbf{8 1 , 2 8 \%}$ \\
\hline
\end{tabular}




\begin{tabular}{|c|l|c|c|c|}
\hline 3. & $\begin{array}{l}\text { Peran Umat Hindu dan Umat Islam } \\
\text { dalam } \\
\text { pelaksanaan tradisi Subak }\end{array}$ & $\mathbf{7 0 3}$ & $\mathbf{9 0 0}$ & $\mathbf{7 8 , 1 1 \%}$ \\
\hline 4. & $\begin{array}{l}\text { Pengaruh akulturasi budaya Subak } \\
\text { antara Umat Hindu dan Islam } \\
\text { terhadap psikologis masyarakat }\end{array}$ & $\mathbf{1 3 0 5}$ & $\mathbf{1 5 0 0}$ & $\mathbf{8 7 \%}$ \\
\hline
\end{tabular}

Berdasarkan data persentase di atas, dapat diperoleh hasil pada indikator pertama yaitu pendapat masyarakat tentang organisasi atau tradisi Subak yang ada di Bali dengan jumlah persentase sebanyak $84,44 \%$ menunjukkan bahwa sebagian besar dari masyarakat terutama pelajar sangat mengetahui apa itu Subak dan bagaimana eksistensi Subak saat ini. Hal ini menyebabkan tradisi Subak masih di gunakan sampai saat ini. Bahkan pada zaman modern ini, Subak tak kalah dari alat-alat canggih yang sudah banyak berkembang di kalangan masyarakat saat ini. Pada indikator kedua yaitu pandangan masyarakat tentang pentingnya organisasi Subak yang ada di Bali dengan persentase sebanyak 81,28\% menunjukkan bahwa pengetahuan atau pandangan masyarakat tentang pentingnya tradisi Subak untuk dilaksanakan pada zaman globalisasi saat ini sangat baik. Petani atau masyarakat mengerti bahwa tradisi Subak merupakan tradisi turun temurun oleh nenek moyang yang harus dijaga sampai saat ini.

Subak sangat penting bagi para petani dalam sistem irigasi persawahan, maka dari itu Subak dijadikan kebutuhan dasar oleh para petani untuk mengatur irigasi persawahannya. Indikator ketiga mengenai peran serta Umat Hindu dan Islam dalam pelaksanaan tradisi Subak dengan persentase sebanyak 78,11\% menunjukkan bahwa masyarakat Hindu maupun Islam sangat berperan penting dalam pelaksanaan tradisi Subak Yeh Santang di Mendoyo, Jembrana. Masyarakat Islam maupun Hindu bersama-sama dalam melaksanakan tradisi Subak dengan bergotong royong dan kerja sama yang sangat baik. Dan hal itu berjalan baik sampai sekarang. Yang terakhir adalah indikator keempat yaitu pengaruh akulturasi budaya Subak antara Umat Hindu dan Islam terhadap psikologis masyarakat dengan persentase sebanyak $87 \%$ yang menunjukkan bahwa perbedaan agama tidak menjadi masalah dalam melaksanakan tradisi Subak. Umat Islam dan Umat Hindu dapat bergotong royong untuk menghasilkan padi yang bagus dan bekerja sama untuk mempertahankan tradisi Subak yang telah ada sejak dulu. Toleransi itu akan menyebabkan adanya sebuah akulturasi budaya yang akan dapat berpengaruh terhadap pola pikir dan perilaku masyarakat kedepannya.

\section{Hasil Penelitian Berupa Wawancara}

Berdasarkan hasil wawancara dengan beberapa narasumber yaitu I Wayan Rudana selaku Kelian Subak Yeh Santang, I Nengah Suda selaku petani yang sering mengurusi sawah di Subak Yeh Santang, I Nyoman Suardika selaku warga Desa Mendoyo. Menurut I Wayan Rudana selaku Kelian Subak Yeh Santang di Mendoyo menyatakan bahwa Subak yang bernama Subak Yeh Santang ada sejak dulu sebelum Umat Islam memasuki pulau Bali yaitu pada abad ke-1 Masehi yaitu sebelum adanya Pura Besakih (pura terbesar di Bali). Sejak saat itu eksistensi Subak dikenal banyak oleh masyarakat Bali dan hampir semua sawah di Bali menggunakan sistem Subak ini. Kemudian pada abad ke-17 Umat Muslim telah masuk ke Bali dan mulai menetap di Bali. Karena sulitnya lapangan pekerjaan Umat Islam pun akhirnya belajar menggarap persawahan seperti yang dilakukan oleh masyarakat Bali. Umat Islam meniru cara Umat Hindu di Bali tentang cara membuat sistem irigasi persawahan untuk memperlancar persawahan yang ada di Bali. Walaupun awalnya tidak sama, tetapi akhirnya mereka mampu menirukannya. Beberapa Umat Islam juga ikut mengurus sawah dengan belajar bersama Umat Hindu dalam tata cara merawat sawah, dan irigasi airnya, walaupun awalnya agak kesulitan, tetapi lama kelamaan mereka akhirnya terbisaa dan mereka dapat mengurus sawah secara bersama-sama sampai sekarang. 
Subak Yeh Santang juga memiliki Aturan atau awig-awig dan parerem yang harus ditaati oleh semua anggota Subak tanpa terkecuali. Di dalam awig-awig Subak dimuat halhal dan ketentuan pokok, isi pokok dalam awig-awig adalah mengatur mengenai hal parahyangan, pawongan dan palemahan sedangkan ketentuan dan hal yang lebih detail di muat di dalam parerem sebagai pelaksanaan awig-awig Subak. awig-awig Subak memuat tentang hak dan kewajiban dari warga Subak serta memuat tentang sanksi atas pelanggaran hak dan kewajiban tersebut. Sanksi yang diberikan ada yang tertulis maupun lisan. Sanksi diputuskan oleh Kelian Subak dan diikuti oleh anggota Subak secara demokratis.

I Nengah Suda selaku petani di Subak Yeh Santang mengaku bekerja sama dengan Umat Islam sangat menyenangkan karena tidak ada lagi perbedaan yang dimiliki oleh keduanya, melainkan sebagai saudara dan saling tolong menolong. I Nengah Suda sudah bertahun-tahun menjadi seorang petani dan tidak mempermasalahkan umat lain ikut bergabung di Subak Yeh Santang itu, ia mengaku ada rasa nyaman ketika bekerja bersamasama di sawah, tidak ada rasa lelah dan terus bersemangat bahkan berlomba untuk mendapat hasil yang maksimal. Yang terakhir adalah I Nyoman Suardika selaku warga di kecamatan Mendoyo, Jembrana menyatakan bahwa kerukunan Umat Hindu dan Umat Islam berjalan sangat baik bahkan ketika hari raya keagamaan, masing-masing agama saling berkunjung atau bersilaturahmi ke rumah masing-masing penduduk. Adanya akulturasi budaya ini menyebabkan adanya rasa menghargai sebuah tradisi yang ada sejak turun-temurun untuk dilestarikan hingga kini.

\section{KESIMPULAN}

Subak adalah tradisi turun-temurun dari Umat Hindu di Bali yang mengatur tentang tata cara irigasi persawahan di Bali. Subak sangat penting dalam mempertahankan persawahan dan kualitas irigasi persawahan di Bali. Atas kerja keras petani dan pemerintah Provinsi Bali, Subak dinobatkan sebagai Situs Warisan Dunia pada tahun 2012 lalu. Itu membuktikan bahwa Subak telah bereksistensi di masyarakat dari Bali hingga ke seluruh Dunia. Akulturasi budaya terjadi di Subak Yeh Santang Mendoyo. Proses terjadinya akulturasi budaya ialah sejak Umat Islam memasuki pulau Bali dan ikut dalam organisasi Subak di Mendoyo tersebut. Umat Hindu dan Islam saling bertukar ilmu yang dimiliki sehingga terciptanya sebuah akulturasi budaya Subak yang sangat memengaruhi psikologis dan karakter pada masyarakat.

Dampak sebuah akulturasi budaya Subak terhadap kondisi psikologis masyarakat sangatlah berpotensi besar karena dalam pelaksanaan Subak dibutuhkan kekompakan, kerja sama dan gotong royong yang terjalin sangat erat sehingga membuat pola pikir yang memengaruhi karakter masyarakat yang mengalami perubahan kearah yang lebih baik. Terlihat dari sebelum adanya akulturasi budaya Subak dan awig-awig Subak sering kali dilanggar oleh masyarakat sedangkan setelah terjadinya akulturasi budaya Subak, pelanggaran awig-awig sangat jarang terjadi bahkan tidak pernah terjadi. Dan juga penyimpangan-penyimpangan di masyarakat berkurang karena masyarakat telah terbiasa untuk hidup rukun dan penuh rasa kekeluargaan.

\section{DAFTAR PUSTAKA}

Armini, Ayu. 2012. Toleransi Masyarakat Multietnis dan Multiagama Dalam Organisasi Subak di Bali. Bali: Balai Pelestarian Nilai Budaya Bali.

BPS. 2018. Penduduk Provinsi Bali Menurut Agama yang Dianut Hasil Sensus Penduduk 2010. Jakarta: BadanPusat Stasistik.

Herawati, Ni Luh. 2015. Pengembangan Pariwisata Berkelanjutan Berbasis Subak Sebagai Bagian Warisan Budaya Dunia UNESCO di Desa Manesta Kabupaten Tabanan. JUMPA 2(1). 79-103. 
Sutawan, N. 2005. Revitalisasi Sistem Subak di Bali. Denpasar: Universitas Udayana.

Sutawan, N. 2008. Organisasi dan Manajemen Subak di Bali. Denpasar: Pustaka Bali Post.

Sudiana, 2008. Identifikasi Upacara-Upacara Keagamaan pada Organisasi Subak di Desa Jatiluwih dan Siyut, Tabanan. Bali.

Windia, I. W., 2002. Transformasi Sistem Irigasi Subak yang Berlandaskan Konsep Tri Hita Karana. Dosertasi Doktor Universitas Gajah Mada, Yogyakarta.

Windia et.al. 2005. Sistem Irigasi Subak Sebagai Landasan Tri Hita Kirana Sebagai Teknologi Sepadan dalam Pertanian Beririgasi. [bagian dari desertasi]. Bali: Universitas Udayana.

Windia, Wayan. 2006. Transformasi Sistem Irigasi Subak yang Berlandaskan Konsep Tri Hita Karana. Pustaka Bali Post, Denpasar.

Wiguna, A.A., 2006. Transformasi Inovasi Teknologi Pertanian dengan Pendekatan Ecofarming pada Ekosistem Subak di Bali. Badan Penelitian dan Pengembangan Pertanian, BPTP, Bali.

Wulandira, A A.A. 2008. "Penerapan Tri Hita Karana di Kawasan Agrowisata Salak Sibetan Karangasem " (unpublised tesis). Denpasar: Universitas Udayana.

Windia, Wayan.dkk. 2015. Sistem Subak di Bali (Kajian Sosiologis). Udayana University Press, Denpasar. 